\title{
PELATIHAN KETERAMPILAN KOMUNIKASI UNTUK MEREDUKSI BULLYING DI TK AL ISLAM 10 SURAKARTA
}

\author{
Eny Kusumawati \\ Universitas Tunas Pembangunan Surakarta \\ enylajanu86@gmail.com
}

\begin{abstract}
This devotional activity was held in Kindergarten Al Islam 10 Surakarta which aims to provide knowledge and skills for school teachers in Al Islam Kindergarten 10 Surakarta as well as parents of parents of parents to know the form of bullying that is often encountered in schools outside the school. In addition, this devotional activity also aims to promote understanding and knowledge to teachers and parents of parents of parents of the parents of al Islam 10 Surakarta kindergarten students about communication skills in reducing the bullying periaku. This activity is planned to be planned by about 20-50 parents of parents and teachers of Al Islam 10 Surakarta Kindergarten. The method of conducting devotion uses lectures and q\&amp;A, demonstrations and practices and mentoring for parents and teachers. This devotional activity will use a guidebook that has been produced by the service team related to ways of communication skills to reduce the bullying behavior of students.

Keywords: Communication Skills, Bullying
\end{abstract}

\begin{abstract}
Abstrak
Kegiatan pengabdian ini dilaksanakan di TK Al Islam 10 Surakarta yang bertujuan untuk memberikan pengetahuan dan ketrampilan bagi guru-guru Sekolah di TK Al Islam 10 Surakarta serta orang tua wali murid untuk mengetahui bentuk dari perlaku bullying yang sering dijumpai disekolah mauapun diluar sekolah. Selain itu kegiatan pengabdian ini juga bertujuan untuk memberrikan pemahaman dan pengetahuan pada guru dan orang tua wali muird sswa TK Al Islam 10 Surakarta tentang ketrampilan berkomunikasi dalam mereduksi periaku bullying tersebut. Kegiatan ini rencananya akan dikuti sekitar 20-50 orang tua wali murid serta guruguru TK Al Islam 10 Surakarta. Metode pelaksanaan pengabdian menggunakan ceramah dan tanya jawab, demonstrasi dan praktek serta pendampingan bagi orang tua dan guru. Kegiatan pengabdian ini nantinya dengan menggunakan buku panduan yang telah dihasilkan oleh tim pengabdian terkait dengan cara-cara ketrampilan berkomunikasi untuk mereduksi perilaku bullying siswa..

Kata Kunci: Ketrampilan Komunikasi, Bullying
\end{abstract}

\begin{tabular}{l|l|l} 
Submitted: $2020-09-16$ & Revised: $2020-10-06$ & Accepted: 2020-10-09
\end{tabular}

\section{Pendahuluan}

Pendidikan adalah hal utama yang dibutuhkan seorang anak dalam tumbuh kembangnya menjadi manusia seutuhnya. Idealnya, seorang anak mendapatkan pendidikan dari institusi terkecil seperti keluarga hingga masyarakat, sekolah bahkan universitas. Bekal pendidikan yang mereka dapatkan dari beragam institusi tersebut akan berperan dalam menentukan keberhasilan di masa yang akan datang.

Sayangnya, Suyata (2000) menegaskan bahwa lembaga pedidikan telah mengalami penurunan kualitas pendidikannya dalam beberapa hal seperti sense of identity, sense of humanity, sense of community, sense of culture (values), dan sense of respect. Kebebasan individual seolah cenderung terikat oleh tujuan lembaga pendidikan 
sehingga pengembangan aspek afektif seperti moral dan budi pekerti menjadi terlupakan. Sering ditemukan adanya persaingan antar teman sebaya yang menyebabkan munculnya stress pada sebagian anak. Hockenberry \& Wilson, (2009) menyatakan adanya persaingan peringkat kelas dengan teman dan dikenal oleh guru atapun serta pemberian label sebagai anak "bodoh" dapat menyebabkan gangguan emosional pada anak. Dalam keseharian, murid di sekolah mitra pelaksanaan kegiatan abdimas ini terkadang ditemukan adanya kesenggangan kecil antar murid. Mengingat usia mereka yang masih cukup belia, permasalahan pergaulan antara mereka memang cukup sepele berupa bullying sehingga sangat dibutuhkan adanya sebuah metode yang dapat membantu mereka mengatasi permasalahan yang mungkin ditimbulkan oleh bullying yang terjadi di lingkugan sekolah.

Perilaku bullying di sekolah merupakan salah satu permasalahan sosial yang kini sangat banyak ditemukan dan memiliki dampak negatif pada kondisi psikologis dan sosial siswa yang pada akhirnya akan mempengaruhi proses belajar mengajar siswa di sekolah. Dalam interaksi komunikasi sehari-hari, dapat dilihat terdapat beberapa faktor yang mungkin mengarah pada bullying. Oleh karena itu, tim pelaksana kegiatan pengabdian kepada masyarakat di SD AL-ISLAM 2 Jmsaren Surakarta merasakan perlunya melaksanakan kegiatan yang berkaitan dengan melatih kemampuan berkomunikasi yang baik antar pendidik dengan murid, orang tua murid dengan murid dan antar murid untuk dapat mereduksi terjadinya bullying.

Kegiatan pengabdian kepada masyarakat ini memberikan pelatihan dengan menggunakan metode ceramah dan diskusi tentang bagaimana meningkatkan keterampilan berkomunikasi. Materi yang digunakan pada pelatihan ini adalah hand out serta buku panduan tentang ketrampilan komunikasi untuk mereduksi perilaku bullying, yang mana buku panduan tersebut berisi materi tentang bagaimana peran para guru dan orang tua dalam mereduksi permasalahan bullying.

\section{Metode}

Kegiatan ini merupakan salah satu wujud dari tridarma perguruan tinggi Universitas Tunas Pembangunan Surakarta. Metode yang dilakukan pada pkegiatan pengabdian ini berupa sosialisasi dan pendampingan terkait ketrampilan mereduksi bullying. berikut rincian metode yang dilaksanakan dalam kegiatan pengabdian ini antara lain:

a. Ceramah dan Tanya Jawab

Metode ini dipilih untuk menjelaskan tentang bentuk perilaku bullying yang biasa dilakukan oleh anak TK serta peyampaian materi terkait bagaimana ketrampilan komunikasi yang tepat bagi guru dan orang tua untuk mereduksi perilaku bullying tersebut.

b. Demonstrasi

Metode ini digunakan untuk menjelaskan suatu proses kerja secara bertahap sehingga dapat memberi kemudahan bagi peserta dapat mengamati secara cermat proses bagaimana ketrampilan komunikasi itu dapat mereduksi bullying.

c. Latihan / Praktek atau Tutorial 
Pada metode ini peserta mempraktekkan ketrampilan komunikasi dengan bimbingan pelatih sehingga peserta dapat mengaplikasikan ketrampilan komunikasi dengan harapan dapat mereduksi bullying dan perilaku bullying berkurang

Sasaran pada kegiatan pengabdian ini adalah khususnya orang tua wali murid TK Al Islam 10 Surakarta. Rencana jangka panjang kegiatan pengabdian ini adalah:

a. Bagi rang tua:

1) kegiatan ini dapat menjadi referensi dalam mendapingi tumbuh kembang putra putrinya untuk mengenali gambaran perilaku bullying yang terjadi pada anak

2) memberikan informasi terkait bullying yang sering dilakukan dan diterima oleh anak-anak sebagai pelaku bullying maupun korban dari bullying

3) dapat mengantisipasi hal-hal buruk yang dimungkinakn terjadi

4) dapat menjalin kerjsama antara orang tua dan guru dalam hal perlaku bullying dan komunikasi yang tepat untuk mengatasi bullying

b. Bagi guru:

1) memberikan informasi dan gambaran perilaku bullying terjadi di sekolah

2) mengenali dan memperdalam keilmuan dampak buruk atau negative yang ditimbulkan bagi pelaku bullying dan siswa sebagai korban bullying

3) memperdalam keilmuan tentang komuniasi efektif dalam menangani dan mengatasi tindakan bullying

4) dapat mengatasi tindakan bullying yang dilakukan siswa di sekolah

Studi analisis kebutuhan yakni menganalisis dan mengindentifikasi perilaku bullying yang sering dilakukan anak dan terjadi pada anak serta menganalisis teknik komunikasi dalam mereduksi perilaku bullying. Rancangan pelaksanaan kegiatan pengabdian ini adalah sebagai berikut:

b. mengidentifikasi pemahaman orang tua dan guru terkait perilaku bullying

c. mengidentifikasi ketrampilan komunikasi yang dimiliki orang tua maupn guru untuk mereduksi perilaku bullying

d. berkolaborasi dengan teman sejawat dan guru dalam hal memberikan penjelasan tentang keuntungan yang akan diperoleh dengan melibatkan teman sejawat/ orang lain

e. Kemampuan dalam ketrampilan berkomunikasi yaitu dengan Memberikan praktek/contoh cara-cara bagaimana ketrampilan berkomunikasi pada yang baik dan tepat pada anak usia TK baik yang melakukan bullying maupun yang menjadi korban bullying

\section{Hasil dan Pembahasan}

Kegiatan pengabdian ini dilaksanakan setiap rapat komite yang dihadiri oleh orang tua dan guru dengan diawali dengan perijinan pada pihak sekolah kemudian melakukan pengidentifikasin terkait perilaku bullying dan cara komunikasi yang efektif dalam mereduksi perilaku bullying serta berkoordinasi denganpihak guru di TK terkait tata pelaksanaan selanjutnya dan pendampingan yang akan dilakukan. Selain itu kegiatan pengabdian juga melibatkan mahasiwa Fakuktas Keguruan dan Ilmu Pendidikan Universitas Tunas Pembangunan Surakarta. 
Pada pelaksanaan pengabdian ini akan diawali oleh ketua pengabdian serta pembicara dalam kegiatan pengabdian ini dengan pemaparan materi yang ahli dibidang parenting yaitu Ibu Eny Kusumawati, M.Pd. setelah pemaparan materi selesai akan dilakukan pendampingan dari ketua pengabdian. Ketua pengabdian selain melakukan pendampingan pada pemaparan materi dan pendampingan untuk praktek dalam menangani perilaku bullying yang dilakukan dan atau yang diterima anak sebagai korban bullying. Pendapingan ini dilakukan terkait dengan cara-cara dalam mengenali dan memahami perilaku bullying serta pendampingan dalam berkomunikasi dengan anak untuk mereduksi perilaku bullying.

Kegiatan pengabdian masyarakat ini dilakukan berdasarkan tahapan-tahapan sebagai berikut :

1. Pra kegiatan

a. Perijinan

Kegiatan perijinan dilakukan dengan memberi surat perijinan kepada pihak sekolah TK Al Islam 10 Surakarta dan meminta guru-guru TK Al Islam 10 Surakarta mendata guru dan orang tua siswa yang siap melakukan kegiatan

b. Melakukan persiapan waktu dan tempat untuk proses pelaksanaan kegiatan. Pembekalan kepada guru-guru di TK Al Islam 10 Surakarta

c. Persiapan alat-alat dan kelengkapan yang dibutuhkan dalam pelaksanaan pelatihan ketrampilan berkomunikasi untuk mereduksi bullying di TK Al Islam 10 Surakarta

2. Pelaksanaan Kegiatan

a. Proses selanjutnya setelah mendapatkan ijin dari pihak kepala sekolah dan daftar nama guru BK yang akan mengikuti kegiatan pengabdian ini.

b. Menyampaikan tujuan dari kegiatan pengabdian serta tahapan dalam kegiatan pengabdian ini. Adapaun tahapan yang akan dilakukan pada kegiatan pengabdian antara lain adalah sebagai berikut :

Tahap I: Pemberian materi tentang pentingnya ketrampilan berkomunikasi untuk mereduksi bullying dan bagaimana cara penerapannya dalam kegiatan pembelajaran di sekolah dengan baik dan tepat maupun penerapnnya ketika siswa berada dilingkungan keluarga atau dilingkungan rumah

Tahap II : Tahap tanya jawab dan diskusi terkait kendala yang kemungkinan dihadapi guru dan orangtua murid di TK Al Islam 10 Surakarta mengenai pentingnya ketrampilan berkomunikasi dalam mereduksi bullying

Tahap III : Tahap ini dilakukan dengan memberikan motivasi kepada guru dan orang tua murid di TK Al Islam 10 Surakarta sebagai bagian dari pelatihan ketrampilan berkomunikasi untuk mereduksi bullying di TK Al Islam 10 Surakarta. Serta guru dan orangtua murid TK Al Islam 10 Surakarta dapat mengkondisikan keadaan siswa dengan ketrampilan berkomunikasi yang tepat dan sesuai.

3. Pasca Kegiatan

Pada tahap ini dengan dilakukannya analisis data dan tolak ukur keberhasilan. Artinya pada tahap ini semua data dianalisis untuk diketahui berhasil tidaknya program ini. Artinya pada tahap ini dilakukan evaluasi untuk mengetahui tingkat keberhasilan dari program ini. Keberhasilan ditunjau dari perubahan pola 
ketrampilan berkomunikasi serta penurunan perilaku bullying yang ada di TK Al Islam 10 Surakarta

\section{Kesimpulan}

Kegiatan pengabdian ini karena belum pernah diadakan pengebadian serupa disekolahan tersebut. Tujuan dari pelaksanaan pengabdian ini adalah untuk mengetahui sebera tingginya tingkat bullying di TK tersebut serta seperti apa bentuk bullying yang dilakukan oleh siswa sehingga diharapkan ketua pengabdian dapat memeberikan sosialisasi serta pendampingan bentuk komunikasi yang baik dan tepat untuk mereduksi perilaku bullying tersebut. Bagi guru kegiatan pengabdian ini bertujuan agar dapat melakukan komunikasi yang baik terhadap perilaku bullying yang terjadi di sekolah serta memberikan arahan bagi siswa. Lebih lanjut, bagi orang tua diharapkan dapat mendapingi serta memperoleh informasi yang tepat cara dalam berkomnikasi pada anak mereka baik sebagai pelaku ataupun korban bullying.

\section{Daftar Pustaka}

Adhani, D. N., \& Hidayah, I. T. (2014). Peningkatan Keterampilan Sosial Anak Melalui Permainan Tradisional Ular-Ularan. Jurnal PG-PAUD Trunojoyo: Jurnal Pendidikan dan Pembelajaran Anak Usia Dini, 1(2), 137-146.

Hurlock, Elizabeth B.2008. Child Development(Perkembangan Anak). Jakarta: Penerbit Erlangga

Veenstra, R., Lindenberg, S., Oldehinkel, A. J., De Winter, A. F., Verhulst, F. C., \& Ormel, J. (2005). Bullying and victimization in elementary schools: a comparison of bullies, victims, bully/victims, and uninvolved preadolescents. Developmental psychology, 41(4), 672. 